\title{
The emerging roles and therapeutic potential of cyclin- dependent kinase 11 (CDK11) in human cancer
}

\author{
Yubing Zhou ${ }^{1,2}$, Jacson K. Shen ${ }^{2}$, Francis J. Hornicek ${ }^{2}$, Quancheng Kan ${ }^{1}$ and \\ Zhenfeng Duan ${ }^{1,2}$ \\ ${ }^{1}$ Department of Pharmacy, The First Affiliated Hospital of Zhengzhou University, Zhengzhou, Henan, People's Republic of \\ China \\ ${ }^{2}$ Sarcoma Biology Laboratory, Center for Sarcoma and Connective Tissue Oncology, Massachusetts General Hospital, Boston, \\ MA, United States of America \\ Correspondence to: Quancheng Kan, email: qckan19632012@163.com
}

Zhenfeng Duan, email: zduan@mgh.harvard.edu

Keywords: CDK 1 1, CDKs inhibitor, cell cycle, therapeutic target, cancer therapy

Received: January 20, $2016 \quad$ Accepted: March 28, $2016 \quad$ Published: March 31, 2016

\section{ABSTRACT}

Overexpression and/or hyperactivation of cyclin-dependent kinases (CDKs) are common features of most cancer types. CDKs have been shown to play important roles in tumor cell proliferation and growth by controlling cell cycle, transcription, and RNA splicing. CDK4/ 6 inhibitor palbociclib has been recently approved by the FDA for the treatment of breast cancer. CDK11 is a serine/threonine protein kinase in the CDK family and recent studies have shown that CDK11 also plays critical roles in cancer cell growth and proliferation. A variety of genetic and epigenetic events may cause universal overexpression of CDK11 in human cancers. Inhibition of CDK11 has been shown to lead to cancer cell death and apoptosis. Significant evidence has suggested that CDK11 may be a novel and promising therapeutic target for the treatment of cancers. This review will focus on the emerging roles of CDK11 in human cancers, and provide a proof-of-principle for continued efforts toward targeting CDK11 for effective cancer treatment.

\section{INTRODUCTION}

Malignant diseases are characterized by uncontrolled cell proliferation and growth [1]. Currently, surgery, radiotherapy, and chemotherapy are still the main modalities in the treatment of cancer [2-4]. Chemotherapy, as one of the basic treatment strategies, is applied in most cancer therapies. However, cancers usually have innate or acquired ability to develop resistance to many anti-cancer drugs, especially in the late stages $[5,6]$. Additionally, most conventional chemotherapy drugs applied in the clinic are non-specific cytotoxic agents and will cause serious adverse effects to patients, thus identifying and developing novel therapeutic strategies is an urgent need for cancer treatment.

Cyclin-dependent kinases (CDKs) are serine/ threonine kinases that play a critical role in the regulation of cell cycle progression, as well as cellular transcription. Distinct CDKs are activated upon binding with their corresponding cyclin partners. Each kinase in this family is coordinated in an orchestrated way, and responsible for particular aspects of the cellular events. Aberrant expression or altered activity of distinct CDK complexes results in escape of cells from the cell cycle control and leads to malignant transformation. Therefore, the inhibition of CDKs in malignant cells provides a promising approach in the defense against cancer. Recently, many selective CDK inhibitors targeting specific CDKs were developed, which represent promising anticancer drugs due to their strong anti-proliferative efficacy combined with a relative low direct cytotoxicity [714]. Notably, palbociclib (IBRANCE ${ }^{\circledR}$ ), a dual CDK4/6 inhibitor, recently received accelerated approval by the Food and Drug Administration (FDA) for clinical breast cancer treatment due to its potent and selective inhibitory effect on estrogen receptor (ER) positive/human epidermal growth factor receptor 2 (HER2) negative breast cancer [15-18]. These developments suggest a promising application of CDK inhibitors as a novel therapeutic strategy in the treatment of human cancer.

CDK11 is a serine/threonine protein kinase in the CDK family. CDK11 also plays a crucial role in cancer 
Table 1: Members of CDK family and their functions in cancers

\begin{tabular}{|c|c|c|c|c|}
\hline $\begin{array}{c}\text { CDK } \\
\text { Family } \\
\end{array}$ & $\begin{array}{l}\text { Cyclins and Cyclin- } \\
\text { like Partners }\end{array}$ & $\begin{array}{l}\text { Gene } \\
\text { Locus }\end{array}$ & Functions in Cancers & Inhibitors \\
\hline CDK1 & $\begin{array}{c}A 1, A 2, B 1, B 2,(B 3) \\
D, E\end{array}$ & $10 q 21.2$ & $\begin{array}{l}\text { promotes cancer cell cycle G2/M } \\
\text { transition and proliferation }\end{array}$ & $\begin{array}{c}\text { Pirarubicin, Flavopiridol, Dinaciclib, } \\
\text { Seliciclib, Roscovitine, Milciclib, } \\
\text { Roniciclib, AZ703, UCN-01, P276- } \\
\text { 00, AT7519, AZD5438, } \\
\text { SCH727965, RGB-286638 }\end{array}$ \\
\hline CDK2 & $\begin{array}{l}\text { A1, A2, B1, B3, D, } \\
\text { E1, E2, Cables1, } \\
\text { SpdYA, SpdYC }\end{array}$ & $12 q 13.2$ & $\begin{array}{l}\text { promotes cancer cell cycle G1/S } \\
\text { transition and proliferation }\end{array}$ & $\begin{array}{c}\text { Seliciclib, Flavopiridol, } \\
\text { Roscovitine, MLN4924, Dinaciclib, } \\
\text { Roniciclib, AZ703, UCN-01, SNS- } \\
\text { 032, AT7519, SCH727965, RGB- } \\
\text { 286638, AZD5438 }\end{array}$ \\
\hline CDK3 & $\begin{array}{l}\text { A1, A2, E1, E2, C } \\
\text { Cables } 1\end{array}$ & $17 q 25.1$ & $\begin{array}{l}\text { helps cancer cells to efficiently } \\
\text { exit the G0 state and enter the G1 } \\
\text { phase, facilitates cell proliferation }\end{array}$ & TG-02, AT-7519, RGB-286638 \\
\hline CDK4 & D1, D2, D3 & $12 q 14.1$ & $\begin{array}{l}\text { promotes cancer cell G1 phase } \\
\text { progression and proliferation }\end{array}$ & $\begin{array}{c}\text { Palbociclib, Flavopiridol, } \\
\text { Abemaciclib, Dinaciclib, Ribociclib, } \\
\text { Milciclib, Roniciclib, P276-00, } \\
\text { LY2835219, AT7519, MM-D37K, } \\
\text { RGB-286638, AZD5438 }\end{array}$ \\
\hline CDK5 & $\begin{array}{l}\text { p35, p39 (D-, E and } \\
\text { G-type cyclins) } \\
\text { Cables } 1\end{array}$ & $7 q 36.1$ & unknown & $\begin{array}{c}\text { Roscovitine, Flavopiridol, Milciclib, } \\
\text { SCH727965, AZD5438, RGB- } \\
286638\end{array}$ \\
\hline CDK6 & D1, D2, D3 & $7 q 21.2$ & $\begin{array}{l}\text { promotes cancer cell G1 phase } \\
\text { progression and proliferation }\end{array}$ & $\begin{array}{c}\text { Palbociclib, Flavopiridol, } \\
\text { Abemaciclib, Ribociclib, } \\
\text { LY2835219, AT7519, RGB-286638 }\end{array}$ \\
\hline CDK7 & $\mathrm{H}$ & $5 q 13.2$ & $\begin{array}{l}\text { promotes cell cycle progress, } \\
\text { RNA transcription, and cancer cell } \\
\text { proliferation }\end{array}$ & $\begin{array}{c}\text { Roscovitine, Flavopiridol, } \\
\text { Roscovitine, Milciclib, Roniciclib, } \\
\text { SNS-032, AT7519, RGB-286638, } \\
\text { AZD5438 }\end{array}$ \\
\hline CDK8 & $\mathrm{C},(\mathrm{K})$ & $13 q 12.13$ & $\begin{array}{l}\text { activates RNA transcription and } \\
\text { promotes cancer cell proliferation }\end{array}$ & unknown \\
\hline CDK9 & $\mathrm{K}, \mathrm{T} 1, \mathrm{~T} 2$ & $9 q 34.11$ & $\begin{array}{c}\text { promotes RNA transcription } \\
\text { elongation and cancer cell } \\
\text { proliferation }\end{array}$ & $\begin{array}{c}\text { Flavopiridol, Roscovitine, } \\
\text { Roniciclib, SNS-032, AZD5438, } \\
\text { P276-00, AT7519, SCH727965, } \\
\text { RGB-286638 }\end{array}$ \\
\hline CDK10 & M & $16 q 24.3$ & $\begin{array}{c}\text { promotes RNA transcription and } \\
\text { cancer cell proliferation }\end{array}$ & unknown \\
\hline CDK11 & D3, L1, L2 & $1 p 36.33$ & $\begin{array}{c}\text { transcription, RNAsplicing; cell } \\
\text { cycle: G2/M }\end{array}$ & unknown \\
\hline CDK12 & L1, L2, K & $17 q 12$ & $\begin{array}{l}\text { promotes RNA transcription } \\
\text { elongation, splicing, and cancer } \\
\text { cell proliferation }\end{array}$ & unknown \\
\hline CDK13 & L1, L2, K & $7 p 14.1$ & $\begin{array}{l}\text { promotes RNA transcription } \\
\text { elongation, splicing, and cancer } \\
\text { cell proliferation }\end{array}$ & unknown \\
\hline CDK14 & D3, Y & $7 q 21.13$ & $\begin{array}{c}\text { links cell cycle regulators and Wnt } \\
\text { signaling, promotes cancer cell } \\
\text { proliferation, migration, and } \\
\text { invasion }\end{array}$ & unknown \\
\hline CDK15 & unknown & $2 q 33.1$ & $\begin{array}{l}\text { promotes cancer cell cycle } \\
\text { progression and proliferation }\end{array}$ & unknown \\
\hline CDK16 & Y, p35, Cables1 & Xp11.3 & $\begin{array}{l}\text { promotes cancer cell cycle } \\
\text { progression and proliferation }\end{array}$ & unknown \\
\hline CDK17 & Cables 1 & $12 q 23.1$ & unknown & unknown \\
\hline CDK18 & $\mathrm{K}, \mathrm{A}$ & $1 q 32.1$ & unknown & unknown \\
\hline CDK19 & C & $6 q 21$ & $\begin{array}{l}\text { activates RNA transcription and } \\
\text { promotes cancer cell proliferation }\end{array}$ & unknown \\
\hline CDK20 & $\mathrm{H}$ & $9 q 22.1$ & unknown & Unknown \\
\hline
\end{tabular}


cell proliferation and growth. Recent studies have found that the overexpression and activation of CDK11 is crucial in the growth and proliferation of cancer cells, including breast cancer, multiple myeloma, osteosarcoma, and other types of cancer, which has suggested that CDK11 may be a novel potential therapeutic target [19-22]. In this review, we discuss the specificity of CDK11 functions, regulation, and interactions in cancers, as well as the potential of targeting CDK11 in cancer treatment.

\section{THE BIOLOGY AND DEREGULATION OF CDKS IN HUMAN CANCERS}

CDKs are a family of serine/threonine (Ser/Thr) protein kinases, composed of a catalytic kinase subunit and a regulatory cyclin subunit, which play crucial roles in cell cycle progression and transcriptional regulation in response to extracellular and intracellular signals [23]. CDKs are characterized by requirement of protein cyclin subunits for enzymatic activity, even though some CDKs can also play other roles without the involvement of cyclins [24]. Until now, based on the sequence similarity and nomenclature, the human CDKs family include members from CDK1 to CDK20 with specific or redundant roles in many aspects of cell growth and proliferation [25]. The evolutionary relationships among these CDK subfamilies have been identified [26].

Generally, CDKs are divided into cell cyclerelated subfamilies and transcription-related subfamilies in regard to their sequencing and main functional roles [26]. Classical cell cycle CDKs, including CDK1, CDK2, CDK4, and CDK6, mainly regulate the transitions between different phases of the cell cycle [27-29]. The cyclin C-CDK3 complex helps the cells to efficiently exit the $\mathrm{G} 0$ state and enter the $\mathrm{G} 1$ phase. In addition, CDK5, CDK11, CDK14, CDK15, CDK16, CDK17, and CDK18 also belong to the cell cycle-related CDK subfamilies, which play different functional roles by regulating diverse cell cycle progress [30-38] (Table 1). On the other hand, transcription-related CDKs subfamilies function mainly via influencing transcription by phosphorylating the carboxy-terminal domain (CTD) of RNA polymerase II (RNAP II), which contains 52 tandem repeats of the consensus heptapeptide amino acid sequence (YSPTSPS) $[39,40]$. Specifically, the transcription-related CDKs subfamilies are comprised of CDK7, CDK8, CDK9, CDK11, CDK12, CDK13, CDK19, and CDK20, which participate in different transcription regulation and exert diverse cellular functions [27, 39-49] (Table 1).

In malignant cells, altered expression of CDKs and their modulators, including overexpression of cyclins and loss of expression of CDK inhibitors, results in deregulated CDK activity, providing a selective growth advantage. In human cancers, owing to various genetic and epigenetic events, CDKs are often overexpressed and/ or overactive, bringing about loss of checkpoint integrity and ultimately resulting in uncontrolled cell proliferation [27, 50-53]. For example, the cyclin D/CDK4/CDK6/RB pathway is hyperactive in various malignancies, such as melanoma, glioblastoma, osteosarcoma, lymphomas, breast and cervical cancers, squamous cell cancer, etc [54]. In the transcriptional CDK subfamily CDK9, aberrant activation has also been observed in several primary tumors, including myeloma, prostate cancer, and lung cancer [55].

Because of their critical roles in cell cycle progression and cellular transcription, as well as in the deregulation of human cancer, CDKs comprise an attractive set of targets for novel anticancer drug development [27]. The best known example is the recently FDA-approved CDK4/6 inhibitor palbociclib as the initial endocrine-based therapy for postmenopausal women with ER+/HER2- metastatic breast cancer. Among other members of the CDK family, CDK11 is involved in both cell cycle control and RNA transcription regulation.

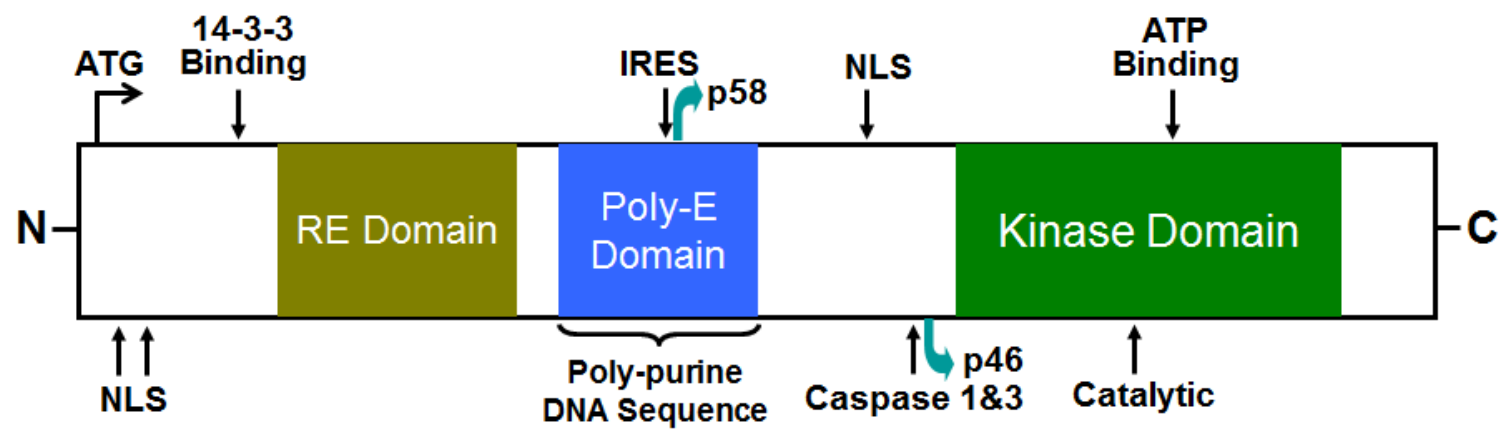

Figure 1: Schematic diagram of the full length CDK11 protein kinase. CDK11 is composed of an N-terminal regulatory region, which has multiple nuclear localization signals (NLS) and a 14-3-3 consensus site, and a carboxy-terminal (C-terminal) catalytic domain that is responsible for its kinase activity. There are two separate domains, an RE domain and a poly-E domain located in the center of the CDK11 protein. The full-length CDK11 ${ }^{\mathrm{p} 110}$ isoform contains an IRES and a caspase-3 site, which leads to the generation of a larger CDK $11^{\mathrm{p} 58}$ and a smaller CDK11 ${ }^{\mathrm{p} 46}$ isoform, respectively (adapted from Trembley et. al., 2004.). NLS, nuclear localization signal; RE, arginine (R) and glutamic (E) acid residues; IRES, internal ribosomal entry site. 
Table 2: Biological characteristics of three main CDK11 isoforms

\begin{tabular}{|c|c|c|c|c|c|c|}
\hline $\begin{array}{c}\text { CDK11 } \\
\text { isoforms }\end{array}$ & $\begin{array}{c}\text { Molecular } \\
\text { Weight }\end{array}$ & $\begin{array}{c}\text { Cyclin } \\
\text { Partners }\end{array}$ & $\begin{array}{c}\text { Subcellular } \\
\text { Localization }\end{array}$ & $\begin{array}{c}\text { Cell Cycle } \\
\text { Expression }\end{array}$ & $\begin{array}{c}\text { Expression } \\
\text { in Cancer }\end{array}$ & Cellular Functions \\
\hline CDK11 ${ }^{\mathrm{p} 110}$ & $110 \mathrm{kDa}$ & $\begin{array}{l}\text { cyclins L1 } \\
\text { and L2 }\end{array}$ & nucleus & $\begin{array}{l}\text { throughout } \\
\text { cell cycle }\end{array}$ & $\begin{array}{c}\text { highly } \\
\text { expressed }\end{array}$ & $\begin{array}{c}\text { transcription } \\
\text { RNA splicing } \\
\text { hedgehog signaling pathway } \\
\text { Wnt/ } \beta \text {-catenin signaling pathway }\end{array}$ \\
\hline CDK11 ${ }^{\text {p58 }}$ & $58 \mathrm{kDa}$ & $\begin{array}{l}\text { cyclins L1, } \\
\text { L2 and D3 }\end{array}$ & $\begin{array}{l}\text { nucleus and } \\
\text { cytoplasm }\end{array}$ & $\begin{array}{l}\text { transiently in } \\
\text { G2/M phase }\end{array}$ & unknown & $\begin{array}{c}\text { mitosis process } \\
\text { centrosome maturation } \\
\text { bipolar spindle assembly }\end{array}$ \\
\hline CDK11 ${ }^{\mathrm{p} 46}$ & $46 \mathrm{kDa}$ & $\begin{array}{l}\text { cyclins L1 } \\
\text { and L2 }\end{array}$ & cytoplasm & transiently & unknown & $\begin{array}{l}\text { apoptosis } \\
\text { autophagy }\end{array}$ \\
\hline
\end{tabular}

CDK11 is functionally relevant to many biologic processes, such as RNA transcription and splicing, mitosis, autophagy, and apoptosis [38, 45, 47, 56, 57]. Recently, distinct and unique biologic roles of CDK11 have been discovered in human cancers and in other human diseases [58].

\section{DISTINCT SPECIFICITY OF CDK11}

Unlike other CDKs encoded only by a single gene, CDK11, formerly known as PITSLRE, is encoded by two highly homologous genes, CDC2L1 (also known as CDK11B) and $C D C 2 L 2$ (also known as CDK11A, nonexistent in mouse) in humans. These two genes are localized in a genomic region that spans about $140 \mathrm{~kb}$ on human chromosome 1 band p36.3 [59]. In mouse, there is only one gene encoding CDK11 [25]. In human, both of the $C D C 2 L$ genes contain 20 exons and 19 introns that encode almost identical protein kinases named CDK11A and CDK11B.

CDK11 is composed of an $\mathrm{N}$-terminal regulatory region, which has multiple nuclear localization signals (NLS) and a 14-3-3 consensus site, and a carboxy-terminal (C-terminal) catalytic domain that is responsible for its kinase activity $[40,60]$. There are two separate domains, an arginine/glutamic acid domain (RE domain) and a poly-glutamic acid domain (poly-E domain) located in the center of the CDK11 protein (Figure 1) [40]. The RE domains are linked to association with RNA processing factors and poly-E domains are emerging as potential cytoskeletal interacting domains that support RE domain function and aide in keeping these proteins subnuclear. The most important conserved amino acids in CDK11 are the PSTAIRE-helix and three phosphorylation sites, which are involved in the activation and repression of CDK kinase activity [40].

CDK11 binds to L-type cyclins and participates in the coordination between transcription and RNA processing, particularly alternative splicing [61]. The functions of CDK11 have been proved to be linked with RNA transcription and processing, regulation of cell cycle, neuronal function, and apoptosis $[38,40,47,56,58]$. The potential for CDK11 to regulate these diverse cellular activities is unique in the CDK family and highlights that CDK11 may exert critical regulatory roles in human tumorigenesis and malignant characteristics of cancer cells.

\section{DIFFERENT ISOFORMS OF CDK11}

Due to the distinct structure and alterative RNA splicing, the $C D C 2 L$ gene can produce three different CDK11 isoforms, a larger $110 \mathrm{kDa}$ protein isoform, a mitosis-specific $58 \mathrm{kDa}$ isoform, and a smaller apoptosisspecific $46 \mathrm{kDa}$ isoform (Table 2). The larger CDK11 1110 isoform is coded by the full-length CDK11 mRNA and contains an internal ribosome entry site (IRES), which leads to the generation of the CDK $11^{\mathrm{p} 58}$ isoform during the $\mathrm{G} 2 / \mathrm{M}$ phase of the cell cycle. In response to apoptotic signaling, both $\mathrm{CDK} 11^{\mathrm{p} 110}$ and $\mathrm{CDK} 11^{\mathrm{p} 58}$ isoforms can be cleaved by caspases 1 and 3 and produce the smaller CDK11 ${ }^{\mathrm{p} 46}$ isoform (Figure 1) [62-64]. These different protein kinase isoforms play diverse cellular functions, including RNA transcription and processing, mitosis, and apoptosis. The larger CDK $11^{\mathrm{p} 110}$ kinase is ubiquitously and constantly expressed throughout the cell cycle. Using subcellular fractionation techniques, the $\mathrm{CDK} 11^{\mathrm{p} 110}$ isoform is proven to be a nuclear protein, which localizes to both splicing factor compartments and to the nucleoplasm [65]. On the other hand, the CDK11 ${ }^{\text {p58 }}$ protein is specifically translated from an internal ribosome entry site and expressed transiently only in the G2/M phase of the cell cycle [66]. Due to the fact that CDK11 ${ }^{\mathrm{p} 58}$ is produced during a very narrow window of mitosis, it is much more difficult to detect than CDK11 $11^{\mathrm{p} 110}$; its detection depends primarily on the mitotic characteristics of a particular cell type $[40,66]$. Although CDK $11^{\mathrm{p} 58}$ shares the same sequences, including the kinase domain at the $\mathrm{C}$-terminus of $\mathrm{CDK} 11^{\mathrm{p} 110}$, the two isoforms possess different functions. The CDK $11^{\mathrm{p} 110}$ isoform is mainly associated with RNA transcription and splicing [40, 45, 60, 61, 67-69], while CDK11 ${ }^{\mathrm{p} 58}$ isoform is involved in mitosis [70-77]. In contrast to CDK11 ${ }^{\mathrm{p} 110}$ and CDK11 ${ }^{\mathrm{p} 58}$, CDK $11^{\mathrm{p} 46}$ localizes to the cytoplasm when ectopically expressed. Like other CDKs, the activation of CDK11 also needs to binding with special cyclins. Cyclins that bind 
Table 3: Characteristics of CDK11 interactiving partners

\begin{tabular}{|c|c|c|c|c|}
\hline $\begin{array}{l}\text { Interacting } \\
\text { Partner }\end{array}$ & $\begin{array}{l}\text { Subcellular } \\
\text { Localization }\end{array}$ & Cellular Functions & Cancer Association & References \\
\hline CHK2 & nucleus & responses to genotoxic stress & $\begin{array}{l}\text { mutation or low expression in breast, } \\
\text { prostate, ovarian, colon, kidney, } \\
\text { thyriod, bladder, lung cancer as well } \\
\text { as sarcomas and leukemias }\end{array}$ & 67 \\
\hline CK2 & nucleus & $\begin{array}{c}\text { promotes cell proliferation and growth, } \\
\text { suppresses cell apoptosis }\end{array}$ & $\begin{array}{c}\text { overexpression or hyperactivation in } \\
\text { lung, breast, prostate, gastric, kidney } \\
\text { cancer as well as AML, CLL and } \\
\text { lymphomas }\end{array}$ & $81 ; 90$ \\
\hline cyclin L1 & nucleus & regulates transcription and RNA splicing & $\begin{array}{l}\text { overexpressed in human head and } \\
\text { neck cancer, and is associated with } \\
\text { lymph node metastases, also amplify } \\
\text { in uterine cervical carcinoma and } \\
\text { associates with poor prognosis }\end{array}$ & $59 ; 61 ; 88$ \\
\hline cyclin L2 & nucleus & $\begin{array}{c}\text { functions as a regulator of the pre-mRNA } \\
\text { splicing process, modulates the } \\
\text { expression of apoptotic and antiapoptotic } \\
\text { proteins }\end{array}$ & $\begin{array}{l}\text { overexpression of cyclin L2 inhibits } \\
\text { cancer cell growth, induces } \\
\text { apoptosis and cell cycle arrest, and } \\
\text { enhances chemosensitivity }\end{array}$ & $59 ; 61 ; 89$ \\
\hline cyclin D3 & $\begin{array}{l}\text { nucleus and } \\
\text { cytoplasm }\end{array}$ & $\begin{array}{l}\text { forms a complex with CDK4 or CDK6, } \\
\text { phosphorylates and inhibits RB protein } \\
\text { and regulates the cell cycle G1/S } \\
\text { transition }\end{array}$ & $\begin{array}{l}\text { overexpressed and associated with a } \\
\text { worse prognosis in patients with } \\
\text { malignant melanoma, breast cancer, } \\
\text { and non-Hodgkin's lymphoma }\end{array}$ & 78 \\
\hline RNPS1 & nucleus & $\begin{array}{l}\text { regulates RNA splicing, promotes mRNA } \\
\text { nuclear export and translation, as well as } \\
\text { maintenance of postsplicing surveillance }\end{array}$ & $\begin{array}{c}\text { overexpressed in mouse } \\
\text { submandibular gland } \\
\text { adenocarcinoma }\end{array}$ & $60 ; 65$ \\
\hline 9G8 & $\begin{array}{l}\text { nucleus and } \\
\text { cytoplasm }\end{array}$ & $\begin{array}{l}\text { regulates RNA splicing, promotes } \\
\text { nucleocytoplasmic export of mRNA and } \\
\text { translate }\end{array}$ & not confirmed & 60 \\
\hline ELL2 & nucleus & $\begin{array}{l}\text { promotes transcription initiation and } \\
\text { elongation, directs immunoglobulin } \\
\text { secretion, inhibits cell growth and } \\
\text { survival, induces cell cycle arrest and } \\
\text { apoptosis }\end{array}$ & $\begin{array}{c}\text { increased expression in leukemia, } \\
\text { mutation associated with multiple } \\
\text { myeloma and salivary gland } \\
\text { carcinoma }\end{array}$ & 45 \\
\hline TFIIF & $\begin{array}{l}\text { nucleus and } \\
\text { cytoplasm }\end{array}$ & $\begin{array}{c}\text { promotes transcription elongation by } \\
\text { interacting with RNAPII throughout the } \\
\text { elongation phase }\end{array}$ & unknown & 45 \\
\hline TFIIS & $\begin{array}{l}\text { nucleus and } \\
\text { cytoplasm }\end{array}$ & $\begin{array}{l}\text { promotes transcription elongation by } \\
\text { enhancing the intrinsic endonucleolytic } \\
\text { cleavage activity of RNAPII }\end{array}$ & unknown & 45 \\
\hline FACT & nucleus & $\begin{array}{l}\text { modulates nucleosome stability and } \\
\text { chromatin remodeling, promotes DNA } \\
\text { replication, recombination, and repair, as } \\
\text { well as transcript elongation }\end{array}$ & $\begin{array}{l}\text { overexpressed in breast carcinoma, } \\
\text { non-small-cell lung cancer, renal cell } \\
\text { carcinoma, and prostatic, pancreatic, } \\
\text { and colorectal adenocarcinomas }\end{array}$ & 45 \\
\hline $\begin{array}{l}\text { RBM15B/O } \\
\text { TT3 }\end{array}$ & $\begin{array}{l}\text { nucleus and } \\
\text { cytoplasm }\end{array}$ & $\begin{array}{c}\text { inhibits spliceosomal E complex } \\
\text { formation, regulates RNA splicing and } \\
\text { mRNA export }\end{array}$ & unknown & 68 \\
\hline $14-3-3$ & nucleus & $\begin{array}{l}\text { regulates cell cycle, protein trafficking, } \\
\text { and steroidogenesis, promotes cell } \\
\text { proliferation, inhibits cell apoptosis }\end{array}$ & $\begin{array}{l}\text { overexpressed in breast, lung, liver, } \\
\text { head and neck cancers, as well as } \\
\text { glioma and astrocytoma }\end{array}$ & 94 \\
\hline Hsp90 & $\begin{array}{l}\text { cytoplasm } \\
\text { and cell } \\
\text { membrane }\end{array}$ & maintains normal tissue homeostasis & $\begin{array}{c}\text { overexpression and/or } \\
\text { hyperactivation in almost all human } \\
\text { cancers }\end{array}$ & 93 \\
\hline Sufu & $\begin{array}{l}\text { nucleus and } \\
\text { cytoplasm }\end{array}$ & promotes embryonic development & $\begin{array}{c}\text { deletion, mutation or } \\
\text { underexpression in lung, breast, } \\
\text { prostate cancer, as well as in } \\
\text { medulloblastoma }\end{array}$ & $91 ; 92$ \\
\hline
\end{tabular}

CDK $11^{\mathrm{p} 110}, \mathrm{CDK} 11^{\mathrm{p} 58}$, and CDK $11^{\mathrm{p} 46}$ are L-type cyclins, which are encoded by two cyclin L genes encoding a total of six isoforms [61]. CDK11 ${ }^{\mathrm{p} 58}$ also binds cyclin D3 [78]. Several non-cyclin partners have also been proposed to interact with $\mathrm{CDK} 11^{\mathrm{p} 46}$, such as eukaryotic initiation factor 3 p47 protein (eIF3 p47) and Ran-binding protein (RanBPM) [79, 80].

\section{FUNCTIONS OF CDK11 IN NORMAL CELLS}

The CDK11 null cells exhibit proliferative defects, mitotic arrest, and apoptosis, thus suggesting that CDK11 kinase is critical for embryonic development and 


\begin{tabular}{|c|c|c|}
\hline Human Cancers & Study Technique & Functions in Tumors \\
\hline Breast Cancer & $\begin{array}{l}\text { immunohistochemistry; RNAi; } \\
\text { immunofluorescence assay; cell viability } \\
\text { assay; cell colony formation assay; cell } \\
\text { migration assay; western blot; flow cytometry } \\
\text { analysis; xenograft RNAi studies }\end{array}$ & $\begin{array}{c}\text { promotes breast cancer cell proliferation, } \\
\text { growth, migration and cell cycle progression; } \\
\text { inhibits breast cancer cell apoptosis, } \\
\text { negatively correlated with breast cancer } \\
\text { patient clinical prognosis }\end{array}$ \\
\hline Osteosarcoma & $\begin{array}{c}\text { systematic Kinome shRNA screening; } \\
\text { CRISPR, RNAi; cell proliferation assay; } \\
\text { apoptosis assay; western blot; } \\
\text { immunofluorescence assay; } \\
\text { immunohistochemistry; xenograft RNAi studies }\end{array}$ & $\begin{array}{l}\text { promotes osteosarcoma cell proliferation, } \\
\text { growth; inhibits osteosarcoma cell } \\
\text { apoptosis; negatively correlated with } \\
\text { osteosarcoma patient clinical prognosis }\end{array}$ \\
\hline Liposarcoma & $\begin{array}{l}\text { immunohistochemistry; RNAi; cell proliferation } \\
\text { assay; western blot; immunofluorescence } \\
\text { assay; chemotherapeutic response assay }\end{array}$ & $\begin{array}{c}\text { promotes liposarcoma cell growth, survival; } \\
\text { inhibits liposarcoma cell apoptosis; } \\
\text { desensitizes liposarcoma cell to } \\
\text { chemotherapy }\end{array}$ \\
\hline Multiple Myeloma & $\begin{array}{l}\text { high-throughput siRNA screening; } \\
\text { RNA microarray hybridization }\end{array}$ & $\begin{array}{c}\text { promotes myeloma cell proliferation and } \\
\text { survival }\end{array}$ \\
\hline Colon Cancer & high-throughput RNAi screening & $\begin{array}{l}\text { acts as a positive modulator of the } \mathrm{Wnt} / \mathrm{\beta} \text { - } \\
\text { catenin pathway in colon cancer }\end{array}$ \\
\hline Cervical Cancer & RNAi; microtubule regrowth assays & $\begin{array}{c}\text { promotes centrosome maturation and } \\
\text { bipolar spindle morphogenesis in cervical } \\
\text { cancer cells }\end{array}$ \\
\hline $\begin{array}{l}\text { Acute Myeloid Leukemia } \\
\text { (AML) }\end{array}$ & CRISPR-based knockout with RNAi & crucial for TSC2-deficient AML cell growth \\
\hline
\end{tabular}

cellular viability [73]. CDK11 knockout mice display an earlier lethality phenotype during the blastocyst stage of embryonic development. The larger CDK11 ${ }^{\mathrm{p} 110}$ isoform, ubiquitously and constantly expressed throughout the cell cycle, is implicated in pre-mRNA splicing and transcription regulation by interacting with numerous proteins involved in the production of RNA transcripts during proliferation, including the largest subunit of RNA polymerase II and casein kinase II [81]. In addition, CDK $11^{\text {p110 }}$ has also been identified as a positive regulator of hedgehog signaling pathway $[82,83]$ as well as a modulator of the $\mathrm{Wnt} / \beta$-catenin signaling cascade [84], both of which play vital roles in the regulation of embryonic development and adult homeostasis [85-87].

\section{UPSTREAM AND DOWNSTREAM REGULATIONS IN CDK11 EXPRESSION AND FUNCTIONS}

The upstream regulation of CDK11 expression has been studied to identify and characterize the CDK11 promoters. As described above, CDK11 is encoded by two highly homologous genes known as $C D C 2 L 1$ and $C D C 2 L 2$. The CDC2L1 gene is regulated by a basal promoter region that is between nucleotides -152 and +11 of the 5 ' region of the $C D C 2 L 1$ gene while a region between nucleotides -145 and +10 of the 5 ' region of $C D C 2 L 2$ is confirmed to be critical for basal transcription of the $C D C 2 L 2$ gene $[88,89]$. In the promoter of the $C D C 2 L 1$ gene, there are transcription factor binding sites for Ets-1 and Skn-1 that are necessary for $C D C 2 L 1$ gene expression [88]. However, CDC2L2 gene expression is mainly regulated by Ets-1 and CREB [89].

Checkpoint kinase 2 (CHK2) and casein kinase 2 (CK2) are confirmed to be the upstream regulators in the CDK11 signaling pathway, which interact with CDK11 via phosphorylating the serine 737 and serine 227 sites, respectively $[67,81,90]$. CDK 11 exerts its functional roles by regulating the expression and/or functions of downstream genes. However, the specific downstream signaling pathway mediated by CDK11 has not been fully documented. Interestingly, a kinase siRNA screen identified CDK11 as a crucial regulator of the Hedgehog pathway [83]. CDK11 was confirmed to directly participate in the Hedgehog signaling pathway by functioning downstream of Smo and upstream of the Glioma-associated (Gli) transcription factors. More specifically, CDK11 interacts with the negative regulator Suppressor of Fused (Sufu) protein and relieves its inhibition of Gli, thus activating the Hedgehog signaling pathway, which is associated with developmental abnormalities and cancer $[91,92]$. In addition, CDK11 has also been proved to be a positive modulator of the 
Wnt/ $\beta$-catenin signaling cascade, whose dysregulation contributes to the development of cancer, using a kinasetargeted high-throughput siRNA screen [84]. Nevertheless, the molecular mechanisms on which CDK11 regulate the $\mathrm{Wnt} / \beta$-catenin signaling pathway remain unclear.

\section{CDK11 INTERACTING PROTEINS AND THE ROLES OF CDK11 IN TRANSCRIPTION AND RNA PROCESSING}

The transcription process of mRNA requires the interaction of a set of general transcription factors and a wide range of gene-specific factors. The mediator complex is one type of large protein complexes, which play critical roles in RNA production and processing. Human mediator complex consists of RNAP II and several positive and negative transcription and RNA processing factors. CDK11 is proven to be a crucial part of the mediator complex. CDK11/cyclin L controls the assembly of the RNAP II mediator complex in fission yeast [69]. To be note, the absence of two conserved domains in the fission yeast CDK11 and cyclin orthologs and the reported essential roles of some CDK11 isoforms in unrelated processes in metazoans propose that CDK11 is essential for human beings gene transcription and processing [71, $74,76]$.

In the regulation of RNA production, CDK11 could directly phosphorylate the CTD of RNAP II and regulates

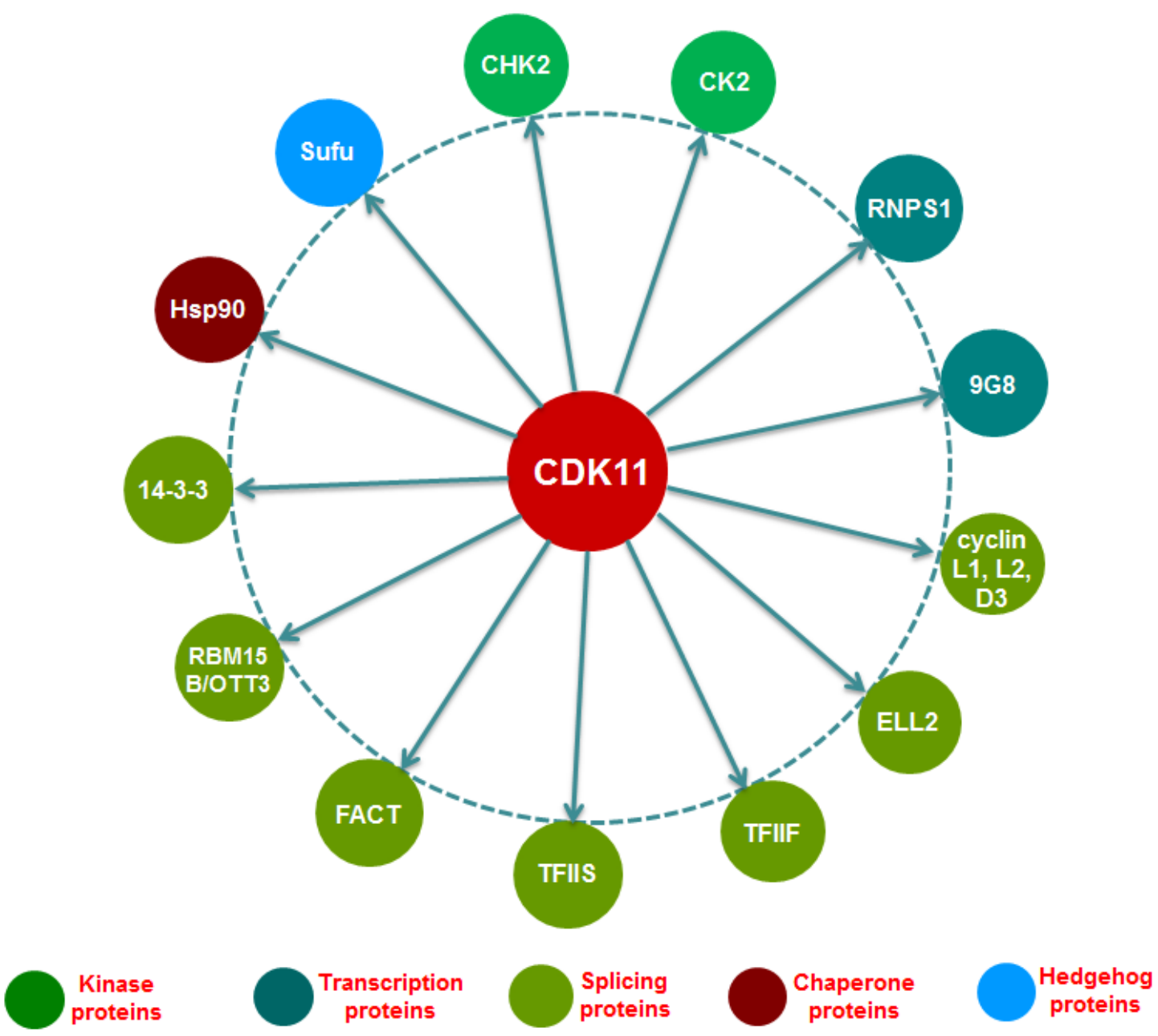

Figure 2: Interacting proteins with CDK11 in transcription and RNA processing. The currently identified CDK11 interacting proteins in the transcription and RNA processing are illustrated in this figure. Among which, the protein kinases CHK2 and CK2 activate CDK11 by phosphorylating the serine 737 and serine 227 sites of the CDK11 kinase, respectively. Cyclin L acts as a crucial protein partner of the CDK11 1110 isoform, while cyclin D3 is essential for functioning for the CDK11 ${ }^{\mathrm{p} 58}$ isoform. RNPSI, 9G8, ELL2, TFIIF, TFIIS, FACT, 14-3-3, and Hsp90 interact with and are subsequently phosphorylated by CDK11. On the other hand, RBM15B/OTT3 interacts with CDK11 as a competitor and antagonizes the positive effect of CDK11 in RNA spicing. Sufu can be negatively regulated by CDK11 and relieve its inhibition on Gli, thus activating the Hedgehog signaling pathway. CHK2, checkpoint kinase 2; CK2, casein kinase 2; RNPS1, RNA-binding protein with serine-rich domain; ELL2, RNA polymerase elongation factor 2; TFIIF, transcription factor IIF; TFIIS, transcription factor IIS; FACT, facilitates chromatin transcription; RBM15B/OTT3, RNA binding motif protein 15 B; Hsp90, heat shock protein 90; Sufu, Suppressor of fused. 
transcription initiation and elongation as well as RNA processing. In addition, CDK11 also exert its roles in the regulation of transcription and/or transcript processing via interacting with numerous transcription regulators and RNA splicing factors.

Several CDK11 interacting protein partners have been identified in the transcription and RNA processing by implementing yeast two-hybrid interactive screens, tandem affinity purification, mass spectrometry analyses, immunoblot, and immunoprecipitation (Figure 2, Table 3 ). The first noteworthy finding is that cyclins L1 and L2 have been well documented as critical cyclin partner proteins of CDK11, which is necessary for the activation of the CDK $11^{\mathrm{p} 110}$ protein isoform [61]. In addition, CDK11 also interacts with splicing factors, such as RNAbinding protein (RNPS1) and 9G8 [60, 65], as well as multiple transcriptional initiation and elongation factors, including RNA polymerase elongation factor 2 (ELL2), transcription factor IIF (TFIIF), transcription factor IIS (TFIIS), and facilitates chromatin transcription (FACT) [45]. RNA binding motif protein 15 B (RBM15B/OTT3) has been shown to interact with $\mathrm{CDK} 11$ as a competitor and antagonizes the positive effect of CDK11 in splicing [68]. CDK11 exerts the biological functions in cell cycle and apoptosis by interacting with several protein partners, including 14-3-3 protein and heat shock protein 70/90 (Hsp70/90) [93, 94].

Currently, there is no specific CDK11 inhibitor, which impedes the CDK11-targeted cancer therapy testing in preclinical models. However, the identification and characterization of these CDK11 interactors may facilitate the understanding of the mechanisms underlying CDK11 functions, as well as the development of therapeutic strategies for cancer. Indeed, some inhibitors targeting these CDK11 interactors have been successfully developed and used in preclinical evaluation or clinical trials, which may provide novel candidate compounds for cancer therapy. For example, CX-4945, a potent and selective small molecule inhibitor of CK2 and a confirmed CDK11 interacting protein, has been investigated for the treatment of prostate cancer [95]. Another small molecular compound, AZD7762, a CHK1/CHK2 (another validated CDK11 partner) inhibitor, has been evaluated in the treatment in patients with advanced solid tumors [96].

\section{EXPRESSION AND THERAPEUTIC POTENTIALS OF CDK11 IN DIFFERENT HUMAN CANCERS}

Due to their critical roles in the growth and proliferation of many types of human cancer, CDKs comprise an attractive set of targets for novel anticancer drugs development. Many CDKs inhibitors are currently being assessed in preclinical or in clinical trial investigations for cancer therapy; among them, a CDK4/6 selective inhibitor palbociclib has recently been approved for breast cancer treatment due to its selected and promising inhibitory effect on ER+/HER2- breast cancer [15-18]. CDK11 function is a critical regulator of cell cycle progression and RNA transcription, and recent studies have suggested that CDK11 also plays important roles in several types of human cancers (Table 4).

\section{CDK11 IN BREAST CANCER}

Recently, the expression and association of CDK11 in human breast cancer has been explored [21]. Immunohistochemical and Western blot assay have revealed that CDK11 is highly expressed in both breast tumor tissues and cell lines. Elevated CDK11 expression in breast cancer tissues significantly correlates with poor differentiation, and is also associated with advanced TNM stage and poor clinical prognosis for breast cancer patients. In vitro knockdown of CDK11 by siRNA significantly inhibits cell growth and migration, and dramatically induces apoptosis in breast cancer cells. Similar results have also been found almost simultaneously by another investigation group, which also showed that CDK11 expression is essential for the maintenance of the aggressive characteristic of triple negative breast cancer (TNBC) [97]. Immunohistochemical analysis of TNBC patient tissues showed that $100 \%$ of tumors stained positive for CDK11 with high nuclear intensity compared to normal tissue. The Cancer Genome Atlas analysis by comparing basal to other breast cancer subtypes, and to normal breast tissues revealed statistically significant differences in CDK11 expression. Downregulation of CDK11 in breast cancer cells resulted in significant loss of cell viability and clonal survival, reduced CDK11 relevant mRNA and protein expression, and induced cell death changes [97]. Furthermore, in vivo treatment with tenfibgen-siCDK11 nanocapsules caused MDAMB-231 xenograft tumor shrinkage, loss of proliferation, and decreased expression of targeted genes. These findings suggest that CDK11 is critical for the survival and proliferation of breast cancer cells, which highlight that CDK11 may be a promising target for therapeutic development in breast cancer.

\section{CDK11 IN MULTIPLE MYELOMA}

A kinase-wide RNAi lethality study using highthrough kinome siRNA screening identified CDK11 as a vulnerable kinase in human multiple myeloma, which proposes that inhibition of CDK11 represents a uniquely targeted novel therapeutic strategy in human multiple myeloma [22]. To better define potential drug targets in myeloma disease, another investigation conducted a focused RNAi lethality screening and consistently found that CDK11 is a crucial survival gene in multiple myeloma [98]. To further assess CDK11 for myelomaselective vulnerability, the study evaluated the expression 
of CDK11 in human multiple myeloma, and showed that CDK11 is significantly upregulated in expression in primary multiple myeloma tissues, as compared with normal human primary tissues. Collectively, CDK11 is overexpressed and functions as a critical survival gene in human multiple myeloma, which suggests that CDK11 may represent a promising druggable target for human multiple myeloma therapy.

\section{CDK11 IN OSTEOSARCOMA}

Osteosarcoma is the most common primary malignant tumor of bone. A kinase shRNA screening first identified CDK11 as essential for the survival of osteosarcoma cells [19]. Osteosarcoma cells display high levels of CDK11 expression, and CDK11 knockdown inhibited cell growth and induced apoptosis in osteosarcoma cells [19]. Moreover, immunohistochemical analysis showed that osteosarcoma patients with high CDK11 expression are associated with significantly shorter survival than patients with low CDK11 expression. Systemic in vivo administration of in vivo ready siRNA of CDK11 reduced tumor growth in an osteosarcoma subcutaneous xenograft model. Furthermore, a recent study using a novel robust and highly efficient genome editing tool, the clustered regularly interspaced short palindromic repeats-Cas9 (CRISPR-Cas9) system, to silence endogenous CDK11 DNA found that CDK11 knockout significantly reduced osteosarcoma cell viability, proliferation, migration, invasion, and induced cell death [99]. All these results show that CDK11 signaling is essential in osteosarcoma cell growth and survival, further elucidating the regulatory mechanisms controlling the expression of CDK11 and ultimately indicate that developing a CDK11 inhibitor may provide therapeutic benefit against osteosarcoma.

\section{CDK11 IN LIPOSARCOMA}

Similarly, the functional and therapeutic relevance of CDK11 as a putative target in liposarcoma, another type of mesenchymal tissue-originated malignancy, was also studied. Immunohistochemical analysis of liposarcoma tissue microarray (TMA) showed that CDK11 is highly expressed in liposarcoma tissues as compared with benign lipoma tissues. CDK11 knockdown by synthetic siRNA or lentiviral shRNA decreased cell proliferation and induced apoptosis in liposarcoma cells. Moreover, CDK11 knockdown enhanced the cytotoxic effect of doxorubicin in liposarcoma cells [20]. These results suggest that CDK11 may be a promising therapeutic target for liposarcoma treatment. Future studies on the signaling pathway and molecular mechanisms of CDK11 and cell growth in liposarcoma are required.

\section{CDK11 IN OTHER TYPE OF HUMAN CANCERS}

The pioneer studies has also confirmed that CDK11 is ubiquitously expressed many human cancer cell lines, such as Jurkat, Cem C7, HeLa, HEK 293, K562, suggesting the potential functional roles of CDK11 in carcinogenesis $[40,100]$. Furthermore, an unbiased high-throughput RNAi screening found that CDK11 is a positive modulator of the $\mathrm{Wnt} / \beta$-catenin pathway in colon cancer [84]. In cervical cancer, CDK11 knockdown by RNAi in HeLa cells induced abnormal spindle assembly, mitotic arrest by checkpoint activation, and cell death [71]. More recently, by using novel CRISPR-based knockouts with RNAi technology, CDK11 has been identified is the crucial gene in cells lacking either the tuberous sclerosis complex 1 (TSC1) or TSC2, but not that of wild-type cells. Mutation or aberrant inhibition of the TSC complex is common in various human tumor cancers. Knockdown of CDK11 showed growth-inhibiting effects in mammalian TSC2-deficient cell lines, including human tumor-derived (AML) cells. TSC1 and TSC2, function together in an evolutionarily conserved protein complex that is a point of convergence for major cell signaling pathways that regulate mTOR complex 1 (mTORC1) [101].

Taken together, CDK11 is usually overexpressed and/or activated in several types of human malignancies, and the overexpression and/or hyperactivation is highly associated with poor outcomes in cancer patients. Consequently, CDK11 may present as a selective and specific target for cancer therapy. The downregulation of expression and activity of CDK11 may be a novel therapeutic modality in cancer treatment.

\section{CDK11 IN OTHER HUMAN DISEASES}

In addition to human cancer, CDKs play important roles in other types of human diseases. Among them, CDK7, CDK9 and CDK13 have been found to be critical for HIV replication inside cells. However, the function of CDK11 remains largely unknown. Recently, CDK11 has been found to regulate the cleavage and polyadenylation (CPA) of all viral transcripts [102, 103]. CDK11 was found to be associated with the TREX/THOC, which recruited this kinase to DNA. Once at the viral genome, CDK11 phosphorylated serines at position 2 in the CTD of RNAP II, which increased levels of CPA factors at the HIV 3' end. Higher levels of CDK11 increased the length of HIV poly(A) tails and the stability of mature viral transcripts. These data suggests that CDK11 also plays an important role in the transcriptional regulation of HIV mRNA.

\section{CONCLUSIONS}

Significant evidences have shown that 
overexpression and hyperactivation of CDKs are common in cancers, and targeting CDK has emerged as a highly promising therapeutic strategy. Specifically, overexpression of CDK11 has been shown to be associated with different cancers recently. As CDK11 has been found to play a crucial role in cancer cell proliferation and growth, CDK11 represents a promising target for novel anti-cancer drug development.

\section{ACKNOWLEDGMENTS}

This work was supported by a Joint Research Fund devoted to clinical pharmacy and precision medicine (Z.D and Q.K). Support has also been provided by the National Natural Science Foundation of China (No.: 81402266 and 81372875), the Gattegno and Wechsler funds. Dr. Zhou is supported by a scholarship from the China Scholarship Council.

\section{CONFLICTS OF INTEREST} interests.

The authors declare that they have no competing

\section{REFERENCES}

1. Hanahan D and Weinberg RA. Hallmarks of cancer: the next generation. Cell. 2011; 144:646-674.

2. Du LL, DeFoe M, Ruzinova MB, Olsen JR and WangGillam A. Perioperative Therapy for Surgically Resectable Pancreatic Adenocarcinoma. Hematol Oncol Clin N. 2015; 29:717-26.

3. Oseledchyk A and Zivanovic O. Intraoperative Hyperthermic Intraperitoneal Chemotherapy in Patients With Advanced Ovarian Cancer. Oncology (Williston Park). 2015; 29.

4. Stone JB and DeAngelis LM. Cancer-treatment-induced neurotoxicity-focus on newer treatments. Nature reviews Clinical oncology. 2016; 13:92-105. doi: 10.1038/ nrclinonc.2015.152.

5. Weisberg E, Manley PW, Cowan-Jacob SW, Hochhaus A and Griffin JD. Second generation inhibitors of BCR$\mathrm{ABL}$ for the treatment of imatinib-resistant chronic myeloid leukaemia. Nature reviews Cancer. 2007; 7:345-356.

6. Gottesman MM, Fojo T and Bates SE. Multidrug resistance in cancer: role of ATP-dependent transporters. Nature reviews Cancer. 2002; 2:48-58.

7. Rath SL and Senapati S. Molecular basis of differential selectivity of cyclobutyl-substituted imidazole inhibitors against CDKs: insights for rational drug design. PloS one. 2013; 8:e73836.

8. Lapenna S and Giordano A. Cell cycle kinases as therapeutic targets for cancer. Nat Rev Drug Discov. 2009; 8:547-566.
9. Choi YJ and Anders L. Signaling through cyclin D-dependent kinases. Oncogene. 2014; 33:1890-1903.

10. Diaz-Moralli S, Tarrado-Castellarnau M, Miranda A and Cascante M. Targeting cell cycle regulation in cancer therapy. Pharmacol Therapeut. 2013; 138:255-271.

11. Shapiro GI. Cyclin-dependent kinase pathways as targets for cancer treatment. J Clin Oncol. 2006; 24:1770-1783.

12. Malinkova V, Vylicil J and Krystof V. Cyclin-dependent kinase inhibitors for cancer therapy: a patent review (2009 2014). Expert opinion on therapeutic patents. 2015; 25:953970.

13. Law ME, Corsino PE, Narayan S and Law BK. CyclinDependent Kinase Inhibitors as Anticancer Therapeutics. Molecular pharmacology. 2015; 88:846-852.

14. Sanchez-Martinez C, Gelbert LM, Lallena MJ and de Dios A. Cyclin dependent kinase (CDK) inhibitors as anticancer drugs. Bioorganic \& medicinal chemistry letters. 2015; 25:3420-3435

15. Finn RS, Crown JP, Lang I, Boer K, Bondarenko IM, Kulyk SO, Ettl J, Patel R, Pinter T, Schmidt M, Shparyk Y, Thummala AR, Voytko NL, Fowst C, Huang X, Kim ST, et al. The cyclin-dependent kinase $4 / 6$ inhibitor palbociclib in combination with letrozole versus letrozole alone as first-line treatment of oestrogen receptor-positive, HER2negative, advanced breast cancer (PALOMA-1/TRIO-18): a randomised phase 2 study. The Lancet Oncology. 2015; 16:25-35.

16. Mangini NS, Wesolowski R, Ramaswamy B, Lustberg MB and Berger MJ. Palbociclib: A Novel Cyclin-Dependent Kinase Inhibitor for Hormone Receptor-Positive Advanced Breast Cancer. The Annals of pharmacotherapy. 2015; 49:1252-60. doi: 10.1177/1060028015602273.

17. Lu J. Palbociclib: a first-in-class CDK4/CDK6 inhibitor for the treatment of hormone-receptor positive advanced breast cancer. Journal of hematology \& oncology. 2015; 8:98.

18. Turner NC, Ro J, Andre F, Loi S, Verma S, Iwata H, Harbeck N, Loibl S, Huang Bartlett C, Zhang K, Giorgetti C, Randolph S, Koehler M and Cristofanilli M. Palbociclib in Hormone-Receptor-Positive Advanced Breast Cancer. The New England journal of medicine. 2015; 373:209-219.

19. Duan Z, Zhang J, Choy E, Harmon D, Liu X, Nielsen P, Mankin H, Gray NS and Hornicek FJ. Systematic kinome shRNA screening identifies CDK11 (PITSLRE) kinase expression is critical for osteosarcoma cell growth and proliferation. Clinical cancer research. 2012; 18:4580-4588.

20. Jia B, Choy E, Cote G, Harmon D, Ye S, Kan Q, Mankin $\mathrm{H}$, Hornicek F and Duan Z. Cyclin-dependent kinase 11 (CDK11) is crucial in the growth of liposarcoma cells. Cancer letters. 2014; 342:104-112.

21. Zhou Y, Han C, Li D, Yu Z, Li F, An Q, Bai H, Zhang X, Duan Z and Kan Q. Cyclin-dependent kinase 11(p110) (CDK11(p110)) is crucial for human breast cancer cell proliferation and growth. Scientific reports. 2015; 5:10433. 
22. Tiedemann RE, Zhu YX, Schmidt J, Yin H, Shi CX, Que Q, Basu G, Azorsa D, Perkins LM, Braggio E, Fonseca $\mathrm{R}$, Bergsagel PL, Mousses S and Stewart AK. Kinomewide RNAi studies in human multiple myeloma identify vulnerable kinase targets, including a lymphoid-restricted kinase, GRK6. Blood. 2010; 115:1594-1604.

23. Manning G, Whyte DB, Martinez R, Hunter $T$ and Sudarsanam S. The protein kinase complement of the human genome. Science. 2002; 298:1912-1934.

24. Lim S and Kaldis P. Cdks, cyclins and CKIs: roles beyond cell cycle regulation. Development. 2013; 140:3079-3093.

25. Malumbres M, Harlow E, Hunt T, Hunter T, Lahti JM, Manning G, Morgan DO, Tsai LH and Wolgemuth DJ. Cyclin-dependent kinases: a family portrait. Nature cell biology. 2009; 11:1275-1276.

26. Malumbres M. Cyclin-dependent kinases. Genome biology. $2014 ; 15: 122$

27. Shapiro GI. Cyclin-dependent kinase pathways as targets for cancer treatment. Journal of clinical oncology. 2006; 24:1770-1783.

28. Aleem E and Arceci RJ. Targeting cell cycle regulators in hematologic malignancies. Frontiers in cell and developmental biology. 2015; 3:16.

29. Cadoo KA, Gucalp A and Traina TA. Palbociclib: an evidence-based review of its potential in the treatment of breast cancer. Breast Cancer (Dove Med Press). 2014; 6:123-133.

30. Kim SH and Ryan TA. CDK5 serves as a major control point in neurotransmitter release. Neuron. 2010; 67:797809.

31. Song WJ, Son MY, Lee HW, Seo H, Kim JH and Chung $\mathrm{SH}$. Enhancement of BACE1 Activity by p25/Cdk5Mediated Phosphorylation in Alzheimer's Disease. PloS one. 2015; 10:e136950.

32. Su SC and Tsai LH. Cyclin-dependent kinases in brain development and disease. Annual review of cell and developmental biology. 2011; 27:465-491.

33. Duan C, Liu Y, Lu L, Cai R, Xue H, Mao X, Chen C, Qian $\mathrm{R}$, Zhang D and Shen A. CDK14 Contributes to Reactive Gliosis via Interaction with Cyclin $\mathrm{Y}$ in Rat Model of Spinal Cord Injury. Journal of molecular neuroscience. 2015.

34. Park MH, Kim SY, Kim YJ and Chung YH. ALS2CR7 (CDK15) attenuates TRAIL induced apoptosis by inducing phosphorylation of survivin Thr34. Biochemical and biophysical research communications. 2014; 450:129-134.

35. Mikolcevic P, Sigl R, Rauch V, Hess MW, Pfaller K, Barisic M, Pelliniemi LJ, Boesl M and Geley S. Cyclindependent kinase 16/PCTAIRE kinase 1 is activated by cyclin $\mathrm{Y}$ and is essential for spermatogenesis. Molecular and cellular biology. 2012; 32:868-879.

36. Demirkan A, van Duijn CM, Ugocsai P, Isaacs A, Pramstaller PP, Liebisch G, Wilson JF, Johansson A, Rudan I, Aulchenko YS, Kirichenko AV, Janssens AC, Jansen
RC, Gnewuch C, Domingues FS, Pattaro C, et al. Genomewide association study identifies novel loci associated with circulating phospho- and sphingolipid concentrations. PLoS genetics. 2012; 8:e1002490.

37. Matsuda S, Kominato K, Koide-Yoshida S, Miyamoto K, Isshiki K, Tsuji A and Yuasa K. PCTAIRE kinase 3/cyclindependent kinase 18 is activated through association with cyclin A and/or phosphorylation by protein kinase A. The Journal of biological chemistry. 2014; 289:18387-18400.

38. Ohno S, Shibayama M, Sato M, Tokunaga A and Yoshida N. Polypyrimidine tract-binding protein regulates the cell cycle through IRES-dependent translation of CDK11(p58) in mouse embryonic stem cells. Cell Cycle. 2011; 10:37063713.

39. Meinhart A, Kamenski T, Hoeppner S, Baumli S and Cramer P. A structural perspective of CTD function. Genes \& development. 2005; 19:1401-1415.

40. Trembley JH, Loyer P, Hu D, Li T, Grenet J, Lahti JM and Kidd VJ. Cyclin dependent kinase 11 in RNA transcription and splicing. Progress in nucleic acid research and molecular biology. 2004; 77:263-288.

41. Firestein R, Bass AJ, Kim SY, Dunn IF, Silver SJ, Guney I, Freed E, Ligon AH, Vena N, Ogino S, Chheda MG, Tamayo P, Finn S, Shrestha Y, Boehm JS, Jain S, et al. CDK8 is a colorectal cancer oncogene that regulates betacatenin activity. Nature. 2008; 455:547-551.

42. Zhao X, Feng D, Wang Q, Abdulla A, Xie XJ, Zhou J, Sun Y, Yang ES, Liu LP, Vaitheesvaran B, Bridges L, Kurland IJ, Strich R, Ni JQ, Wang C, Ericsson J, et al. Regulation of lipogenesis by cyclin-dependent kinase 8-mediated control of SREBP-1. The Journal of clinical investigation. 2012; 122:2417-2427.

43. Yu DS, Zhao R, Hsu EL, Cayer J, Ye F, Guo Y, Shyr Y and Cortez D. Cyclin-dependent kinase 9-cyclin $\mathrm{K}$ functions in the replication stress response. EMBO reports. 2010; 11:876-882.

44. Guen VJ, Gamble C, Flajolet M, Unger S, Thollet A, Ferandin Y, Superti-Furga A, Cohen PA, Meijer L and Colas P. CDK10/cyclin M is a protein kinase that controls ETS2 degradation and is deficient in STAR syndrome. Proceedings of the National Academy of Sciences of the United States of America. 2013; 110:19525-19530.

45. Trembley JH, Hu D, Hsu LC, Yeung CY, Slaughter C, Lahti JM and Kidd VJ. PITSLRE p1 10 protein kinases associate with transcription complexes and affect their activity. The Journal of biological chemistry. 2002; 277:2589-2596.

46. Cheng SW, Kuzyk MA, Moradian A, Ichu TA, Chang VC, Tien JF, Vollett SE, Griffith M, Marra MA and Morin GB. Interaction of cyclin-dependent kinase 12/CrkRS with cyclin $\mathrm{K} 1$ is required for the phosphorylation of the C-terminal domain of RNA polymerase II. Molecular and cellular biology. 2012; 32:4691-4704.

47. Liu X, Cheng C, Shao B, Wu X, Ji Y, Lu X and Shen A. LPS-stimulating astrocyte-conditioned medium causes 
neuronal apoptosis via increasing CDK11(p58) expression in $\mathrm{PC} 12$ cells through downregulating AKT pathway. Cellular and molecular neurobiology. 2013; 33:779-787.

48. Mukhopadhyay A, Kramer JM, Merkx G, Lugtenberg D, Smeets DF, Oortveld MA, Blokland EA, Agrawal J, Schenck A, van Bokhoven H, Huys E, Schoenmakers EF, van Kessel AG, van Nouhuys CE and Cremers FP. CDK19 is disrupted in a female patient with bilateral congenital retinal folds, microcephaly and mild mental retardation. Human genetics. 2010; 128:281-291.

49. Feng H, Cheng AS, Tsang DP, Li MS, Go MY, Cheung YS, Zhao GJ, Ng SS, Lin MC, Yu J, Lai PB, To KF and Sung JJ. Cell cycle-related kinase is a direct androgen receptorregulated gene that drives beta-catenin/T cell factordependent hepatocarcinogenesis. The Journal of clinical investigation. 2011; 121:3159-3175.

50. Canavese M, Santo L and Raje N. Cyclin dependent kinases in cancer: potential for therapeutic intervention. Cancer biology \& therapy. 2012; 13:451-457.

51. Chen TJ, Lee SW, Lin LC, Lin CY, Chang KY and Li CF. Cyclin-dependent kinase 4 overexpression is mostly independent of gene amplification and constitutes an independent prognosticator for nasopharyngeal carcinoma. Tumour biology. 2014; 35:7209-7216.

52. Diaz-Moralli S, Tarrado-Castellarnau M, Miranda A and Cascante M. Targeting cell cycle regulation in cancer therapy. Pharmacology \& therapeutics. 2013; 138:255-271.

53. Park S, Lee J, Do IG, Jang J, Rho K, Ahn S, Maruja L, Kim SJ, Kim KM, Mao M, Oh E, Kim YJ, Kim J and Choi YL. Aberrant CDK4 amplification in refractory rhabdomyosarcoma as identified by genomic profiling. Scientific reports. 2014; 4:3623.

54. Lapenna S and Giordano A. Cell cycle kinases as therapeutic targets for cancer. Nature reviews Drug discovery. 2009; 8:547-566.

55. Romano $\mathrm{G}$ and Giordano A. Role of the cyclin-dependent kinase 9-related pathway in mammalian gene expression and human diseases. Cell Cycle. 2008; 7:3664-3668.

56. Loyer P, Trembley JH, Katona R, Kidd VJ and Lahti JM. Role of CDK/cyclin complexes in transcription and RNA splicing. Cellular signalling. 2005; 17:1033-1051.

57. Wilkinson S, Croft DR, O'Prey J, Meedendorp A, O'Prey $\mathrm{M}$, Dufes $\mathrm{C}$ and Ryan KM. The cyclin-dependent kinase PITSLRE/CDK11 is required for successful autophagy. Autophagy. 2011; 7:1295-1301.

58. Bajic VP, Su B, Lee HG, Kudo W, Siedlak SL, Zivkovic L, Spremo-Potparevic B, Djelic N, Milicevic Z, Singh AK, Fahmy LM, Wang X, Smith MA and Zhu X. Mislocalization of CDK11/PITSLRE, a regulator of the G2/M phase of the cell cycle, in Alzheimer disease. Cellular \& molecular biology letters. 2011; 16:359-372.

59. Gururajan R, Lahti JM, Grenet J, Easton J, Gruber I, Ambros PF and Kidd VJ. Duplication of a genomic region containing the Cdc2L1-2 and MMP21-22 genes on human chromosome 1p36.3 and their linkage to D1Z2. Genome research. 1998; 8:929-939.

60. Hu D, Mayeda A, Trembley JH, Lahti JM and Kidd VJ. CDK11 complexes promote pre-mRNA splicing. The Journal of biological chemistry. 2003; 278:8623-8629.

61. Loyer P, Trembley JH, Grenet JA, Busson A, Corlu A, Zhao W, Kocak M, Kidd VJ and Lahti JM. Characterization of cyclin L1 and L2 interactions with CDK11 and splicing factors: influence of cyclin L isoforms on splice site selection. The Journal of biological chemistry. 2008; 283:7721-7732.

62. Lahti JM, Xiang J, Heath LS, Campana D and Kidd VJ. PITSLRE protein kinase activity is associated with apoptosis. Molecular and cellular biology. 1995; 15:1-11.

63. Beyaert R, Kidd VJ, Cornelis S, Van de Craen M, Denecker G, Lahti JM, Gururajan R, Vandenabeele P and Fiers W. Cleavage of PITSLRE kinases by ICE/CASP-1 and CPP32/ CASP-3 during apoptosis induced by tumor necrosis factor. The Journal of biological chemistry. 1997; 272:1169411697.

64. Ariza ME, Broome-Powell M, Lahti JM, Kidd VJ and Nelson MA. Fas-induced apoptosis in human malignant melanoma cell lines is associated with the activation of the p34(cdc2)-related PITSLRE protein kinases. The Journal of biological chemistry. 1999; 274:28505-28513.

65. Loyer P, Trembley JH, Lahti JM and Kidd VJ. The RNP protein, RNPS1, associates with specific isoforms of the p34cdc2-related PITSLRE protein kinase in vivo. Journal of cell science. 1998; 111:1495-1506.

66. Cornelis S, Bruynooghe Y, Denecker G, Van Huffel S, Tinton $\mathrm{S}$ and Beyaert R. Identification and characterization of a novel cell cycle-regulated internal ribosome entry site. Molecular cell. 2000; 5:597-605.

67. Choi HH, Choi HK, Jung SY, Hyle J, Kim BJ, Yoon K, Cho EJ, Youn HD, Lahti JM, Qin J and Kim ST. CHK2 kinase promotes pre-mRNA splicing via phosphorylating CDK11(p110). Oncogene. 2014; 33:108-115.

68. Loyer P, Busson A, Trembley JH, Hyle J, Grenet J, Zhao W, Ribault C, Montier T, Kidd VJ and Lahti JM. The RNA binding motif protein 15B (RBM15B/OTT3) is a functional competitor of serine-arginine (SR) proteins and antagonizes the positive effect of the CDK11p110-cyclin L2alpha complex on splicing. The Journal of biological chemistry. 2011; 286:147-159.

69. Drogat J, Migeot V, Mommaerts E, Mullier C, Dieu M, van Bakel H and Hermand D. Cdk11-cyclinL controls the assembly of the RNA polymerase II mediator complex. Cell reports. 2012; 2:1068-1076.

70. Franck N, Montembault E, Rome P, Pascal A, Cremet JY and Giet R. CDK11(p58) is required for centriole duplication and Plk4 recruitment to mitotic centrosomes. PloS one. 2011; 6:e14600.

71. Petretti C, Savoian M, Montembault E, Glover DM, Prigent $\mathrm{C}$ and Giet R. The PITSLRE/CDK11p58 protein 
kinase promotes centrosome maturation and bipolar spindle formation. EMBO reports. 2006; 7:418-424.

72. Hu D, Valentine M, Kidd VJ and Lahti JM. CDK11(p58) is required for the maintenance of sister chromatid cohesion. Journal of cell science. 2007; 120:2424-2434.

73. Li T, Inoue A, Lahti JM and Kidd VJ. Failure to proliferate and mitotic arrest of CDK11(p110/p58)-null mutant mice at the blastocyst stage of embryonic cell development. Molecular and cellular biology. 2004; 24:3188-3197.

74. Yokoyama H, Gruss OJ, Rybina S, Caudron M, Schelder M, Wilm M, Mattaj IW and Karsenti E. Cdk11 is a RanGTPdependent microtubule stabilization factor that regulates spindle assembly rate. The Journal of cell biology. 2008; 180:867-875.

75. Barna M, Pusic A, Zollo O, Costa M, Kondrashov N, Rego E, Rao PH and Ruggero D. Suppression of Myc oncogenic activity by ribosomal protein haploinsufficiency. Nature. 2008; 456:971-975.

76. Wilker EW, van Vugt MA, Artim SA, Huang PH, Petersen CP, Reinhardt HC, Feng Y, Sharp PA, Sonenberg N, White FM and Yaffe MB. 14-3-3sigma controls mitotic translation to facilitate cytokinesis. Nature. 2007; 446:329-332.

77. Rakkaa T, Escude C, Giet R, Magnaghi-Jaulin L and Jaulin C. CDK11(p58) kinase activity is required to protect sister chromatid cohesion at centromeres in mitosis. Chromosome research. 2014; 22:267-276.

78. Zhang S, Cai M, Xu S, Chen S, Chen X, Chen C and Gu J. Interaction of p58(PITSLRE), a G2/M-specific protein kinase, with cyclin D3. The Journal of biological chemistry. 2002; 277:35314-35322.

79. Shi J, Feng Y, Goulet AC, Vaillancourt RR, Sachs NA, Hershey JW and Nelson MA. The p34cdc2-related cyclindependent kinase 11 interacts with the p47 subunit of eukaryotic initiation factor 3 during apoptosis. The Journal of biological chemistry. 2003; 278:5062-5071.

80. Mikolajczyk M, Shi J, Vaillancourt RR, Sachs NA and Nelson M. The cyclin-dependent kinase 11(p46) isoform interacts with RanBPM. Biochemical and biophysical research communications. 2003; 310:14-18.

81. Trembley JH, Hu D, Slaughter CA, Lahti JM and Kidd VJ. Casein kinase 2 interacts with cyclin-dependent kinase 11 (CDK11) in vivo and phosphorylates both the RNA polymerase II carboxyl-terminal domain and CDK11 in vitro. The Journal of biological chemistry. 2003; 278:22652270 .

82. Nybakken K, Vokes SA, Lin TY, McMahon AP and Perrimon N. A genome-wide RNA interference screen in Drosophila melanogaster cells for new components of the Hh signaling pathway. Nature genetics. 2005; 37:13231332.

83. Evangelista M, Lim TY, Lee J, Parker L, Ashique A, Peterson AS, Ye W, Davis DP and de Sauvage FJ. Kinome siRNA screen identifies regulators of ciliogenesis and hedgehog signal transduction. Science signaling. 2008; 1:ra7.

84. Naik S, Dothager RS, Marasa J, Lewis CL and PiwnicaWorms D. Vascular Endothelial Growth Factor Receptor-1 Is Synthetic Lethal to Aberrant \{beta\}-Catenin Activation in Colon Cancer. Clinical cancer research. 2009; 15:75297537.

85. Jiang J and Hui CC. Hedgehog signaling in development and cancer. Developmental cell. 2008; 15:801-812.

86. Petrova R and Joyner AL. Roles for Hedgehog signaling in adult organ homeostasis and repair. Development. 2014; 141:3445-3457.

87. MacDonald BT, Tamai $\mathrm{K}$ and $\mathrm{He} \mathrm{X}$. Wnt/beta-catenin signaling: components, mechanisms, and diseases. Developmental cell. 2009; 17:9-26.

88. Kahle A, Feng Y and M AN. Isolation and characterization of the human Cdc2L1 gene promoter. Gene. 2005; 344:5360.

89. Feng Y, Goulet AC and Nelson MA. Identification and characterization of the human $\mathrm{Cdc} 212$ gene promoter. Gene. 2004; 330:75-84.

90. Sachs NA and Vaillancourt RR. Cyclin-dependent kinase 11 (p110) activity in the absence of CK2. Biochimica et biophysica acta. 2003; 1624:98-108.

91. Kugler MC, Joyner AL, Loomis CA and Munger JS. Sonic hedgehog signaling in the lung. From development to disease. American journal of respiratory cell and molecular biology. 2015; 52:1-13.

92. Briscoe $\mathrm{J}$ and Therond PP. The mechanisms of Hedgehog signalling and its roles in development and disease. Nature reviews Molecular cell biology. 2013; 14:416-429.

93. Mikolajczyk M and Nelson MA. Regulation of stability of cyclin-dependent kinase CDK11p110 and a caspaseprocessed form, CDK11p46, by Hsp90. The Biochemical journal. 2004; 384:461-467.

94. Feng Y, Qi W, Martinez J and Nelson MA. The cyclindependent kinase 11 interacts with 14-3-3 proteins. Biochemical and biophysical research communications. 2005; 331:1503-1509.

95. Pierre F, Chua PC, O’Brien SE, Siddiqui-Jain A, Bourbon P, Haddach M, Michaux J, Nagasawa J, Schwaebe MK, Stefan E, Vialettes A, Whitten JP, Chen TK, Darjania L, Stansfield R, Bliesath J, et al. Pre-clinical characterization of CX-4945, a potent and selective small molecule inhibitor of CK2 for the treatment of cancer. Molecular and cellular biochemistry. 2011; 356:37-43.

96. Seto T, Esaki T, Hirai F, Arita S, Nosaki K, Makiyama A, Kometani T, Fujimoto C, Hamatake M, Takeoka H, Agbo F and Shi X. Phase I, dose-escalation study of AZD7762 alone and in combination with gemcitabine in Japanese patients with advanced solid tumours. Cancer chemotherapy and pharmacology. 2013; 72:619-627.

97. Kren BT, Unger GM, Abedin MJ, Vogel RI, Henzler CM, Ahmed K and Trembley JH. Preclinical evaluation of cyclin dependent kinase 11 and casein kinase 2 survival kinases as 
RNA interference targets for triple negative breast cancer therapy. Breast cancer research. 2015; 17:19.

98. Tiedemann RE, Zhu YX, Schmidt J, Shi CX, Sereduk $\mathrm{C}$, Yin H, Mousses S and Stewart AK. Identification of molecular vulnerabilities in human multiple myeloma cells by RNA interference lethality screening of the druggable genome. Cancer research. 2012; 72:757-768.

99. Feng Y, Sassi S, Shen JK, Yang X, Gao Y, Osaka E, Zhang J, Yang S, Yang C, Mankin HJ, Hornicek FJ and Duan Z. Targeting CDK11 in osteosarcoma cells using the CRISPR-Cas9 system. Journal of orthopaedic research. 2015; 33:199-207.

100. Xiang J, Lahti JM, Grenet J, Easton J and Kidd VJ. Molecular cloning and expression of alternatively spliced PITSLRE protein kinase isoforms. The Journal of biological chemistry. 1994; 269:15786-15794.
101. Housden BE, Valvezan AJ, Kelley C, Sopko R, Hu Y, Roesel C, Lin S, Buckner M, Tao R, Yilmazel B, Mohr SE, Manning BD and Perrimon N. Identification of potential drug targets for tuberous sclerosis complex by synthetic screens combining CRISPR-based knockouts with RNAi. Science signaling. 2015; 8:rs9.

102. Pak V, Eifler TT, Jager S, Krogan NJ, Fujinaga K and Peterlin BM. CDK11 in TREX/THOC Regulates HIV mRNA 3' End Processing. Cell host \& microbe. 2015; 18:560-570.

103. Cary DC, Fujinaga K and Peterlin BM. Molecular mechanisms of HIV latency. The Journal of clinical investigation. 2016:1-7. 